\title{
Meaning, Understanding and Action
}

\author{
Roger Teichmann \\ University of Oxford \\ roger.teichmann@st-hildas.ox.ac.uk
}

Reception date: 8-10-2019

Acceptance date: 9-12-2019

\begin{abstract}
The criteria for a learner's understanding the words of a language include acting appropriately. In the case of Anscombean modals (e.g., 'You have to $\varphi$ '), these actions include whatever is specified in the modal statement (e.g., $\varphi$-ing). Teaching language means instilling not just abilities, but inclinations, to do certain things. With non-learners there is a default presumption of linguistic competence, and this explains how an adult can be said to understand 'You have to $\varphi$ ' while being generally disinclined to respond appropriately, i.e., by $\varphi$-ing. (Dishonesty.) It's possible for it to become normal for the members of some societal group to fail to respond appropriately to modal statements; such a situation may be one of conceptual and practical confusion, with the sort of corresponding bad faith alleged by Anscombe in connection with the 'moral ought'. Since understanding modal statements is manifested in forms of voluntary action, the internalist view that one only has reason to obey a rule if doing so is conducive to the satisfaction of one's desires turns out to be incoherent.
\end{abstract}

Keywords: Anscombe; Wittgenstein; stopping modals; language; rules; internalism

\section{Resum. Significat, comprensió i acció}

Els criteris perquè un estudiant entengui les paraules d'un idioma inclouen actuar de manera apropiada. En el cas de la lògica modal d'Anscombe (p. ex. Haver de $\varphi$ ), aquestes accions inclouen el que s'especifica en la declaració modal (p. ex. gerundi-gerundi). Ensenyar un idioma significa inculcar no només habilitats sinó també inclinacions per fer certes coses. En el cas dels no estudiants, existeix una presumpció predeterminada de competència lingüística, $\mathrm{i}$ això explica que es pugui dir que un adult comprèn «Ha de» mentre que generalment no està disposat a respondre adequadament, és a dir, fent $\varphi$-gerundi. (Deshonestedat.) És possible que es consideri normal que els membres d'algun grup social no responguin adequadament a les declaracions modals. Aquesta situació pot ser resultat d'una confusió conceptual i pràctica, amb el tipus de mala fe corresponent al-legada per Anscombe en relació amb el "deure moral». Atès que la comprensió de les declaracions modals es manifesta en formes d'acció voluntària, resulta incoherent la visió internalista que un només té raons per obeir una regla si fer-ho és propici per satisfer els desitjos.

Paraules clau: Anscombe; Wittgenstein; modals d'interrupció; llenguatge; regles; internalisme 


\section{Summary}

1. Understanding stopping
and forcing modals

2. Abilities and inclinations

3. Illusion and confusion
4. Travails of internalism

5. Conclusion

Bibliographical references

\section{Understanding stopping and forcing modals}

When does a child count as understanding the meaning of 'plus'? Roughly speaking, when she has sufficiently mastered the skill of addition; in other words, when she often enough uses 'plus' (' + ') in the right way, where that especially means: doing correct calculations employing the symbol. 'Often enough' is of course vague. We encounter the same vagueness when faced with the question, 'When can a child play the piano?' Answer: when she sufficiently often gets things sufficiently right on the piano (playing scales, pieces, etc.).

There is a general point here about language-mastery. As Wittgenstein famously wrote: 'For a large class of cases...in which we employ the word "meaning" it can be defined thus: the meaning of a word is its use in the language' (PI 43). ${ }^{1}$ Using a word is a form of activity. To characterise the use of a word, one will often need to locate that use within a certain language-game, i.e., a rule-governed practice in which various words or expressions are used in interlocking ways. The term 'rule-governed' here points to the difference between correct and incorrect uses of words. Understanding a word means having the ability to use it correctly, often enough.

Although all word use may be called 'activity', involving various kinds of actions (assertion, questioning, exclamation, apology...), there are certain uses of words which are bound up with action in a very direct way. I have in mind two kinds of language-game: that involving imperatives, and that involving what Anscombe calls stopping and forcing modals. When does a child count as understanding the meaning of such imperative forms as 'Come here', 'Pass the butter' or 'Don't do that'? The natural answer is: 'When she responds appropriately often enough.' And 'responding appropriately' presumably means obeying or complying with the command or request. (Perhaps we should additionally require that she develop the ability to use imperatives herself.)

Stopping and forcing modals are linguistic cousins of imperatives. Anscombe introduces them in the course of explicating, and then jumping free of, a certain circularity that we are liable to encounter when we try to say what a promise is (see, e.g., Anscombe, 1981a, 1981d). To say what a promise is, we need at least to say this: that if you promise to $\varphi$, you bring it about that you

1. I will refer to Wittgenstein's Philosophical Investigations (Wittgenstein, 1958) as 'PI'; unless otherwise specified, numbers refer to the numbered sections of Part I of that work. 
have to $\varphi$. But what does 'have to' mean? Is it this: that you have to $\varphi$, or you'll upset the other person? But you might not upset them; they might never even discover that you broke the promise. Moreover, perhaps I would upset someone to whom I'd expressed an intention (to be at a meeting, say) if I changed my mind and didn't do what I said I'd do; but that fact wouldn't turn my expression of intention into a promise. How about this: you have to $\varphi$, because if you don't you'll commit a wrong? But how shall we say what the 'wrong' is, except by calling it 'breaking a promise'? (A circle.) So is it this: you have to $\varphi$ if you wish to obey the Rule of Promising? But what is the rule? Isn't it: If you promise to $\varphi$, you have to $\varphi$ ? (Another circle.) We still haven't explained this 'have to'.

Anscombe notes that we will be unable to solve this problem so long as we attempt to give non-circular analyses of such expressions as 'promise' and 'have to' (or of sentences employing them). She proposes that we instead look to how these words are used, and especially to how they are taught and learnt. This is what she does; and her investigation yields a number of findings, one of which concerns the difference between mere imperatives, such as 'Move your king', and statements like 'You have to move your king'. The meaning and function of the latter, she points out, is bound up with another kind of statement, which she calls a logos; the logos might for example be 'Your king is in check'. In the case of promising, 'You promised to do X' would be a logos for 'You have to do X', and the meanings of these two statements cannot be understood independently of one another. They must be learnt together as part of a package deal.

'Stopping/forcing modal' and 'logos' are technical terms, for which Anscombe does not give explicit definitions, reasonably enough. Should we take the characteristic just mentioned, of there being a mutual conceptual dependence between logoi and their correlative modal statements, as definitive of logoi? It seems not. For you could, e.g., take some already-grasped concept and stipulate that this concept is to have the reason-giving force of a logos in the game you are inventing or explaining. 'Everyone dances around and when the music stops, you have to sit on a chair if you can.' This rule yields such statements as 'You have to sit down - the music has stopped!' Clearly, we understand the meaning of 'The music has stopped' independently of learning the rule. Nevertheless, it can be said that one learns a new role for 'The music has stopped', and understanding this role is indeed tied up with understanding the meaning of 'You have to sit down'.

When does a child count as understanding the meaning of the modal, 'You have to' ('You're meant to', etc.)? She needs to be able to ask or answer the question 'Why?'; if asked it, she'll need to be able to give a logos, for instance by saying 'Your king is in check'. If 'You have to' is addressed to the child and an appropriate logos is given, then presumably she'll need to respond appropriately often enough if she is to count as having mastered this bit of language. As with imperatives, 'responding appropriately' means doing the thing which she 'has to' do. 
Normal adults understand imperatives and understand stopping/forcing modals. They were taught the use of these expressions as children and have not forgotten how to use them. So if understanding is a matter of 'responding appropriately', can we infer that any normal adult will typically, or even quite often, obey authoritative commands, comply with requests, keep promises... and generally speaking not break the rules? Would that it were so! What, then, is the difference between my not understanding the rules of poker and my cheating at poker? What is the difference between my failing to grasp that I should keep a promise and my simply ignoring the obligation which I have put myself under?

The significance of such questions is at once conceptual and ethical. (Philosophy and ethics are continuous.) The ethical aspect of the issue can be seen in the fact that someone's not understanding a rule will typically excuse his breaking it; in many cases we might even decide that such inadvertent rule-breaking isn't rule-breaking at all, strictly speaking. I say 'typically excuse' because a lack of understanding of this sort isn't always taken to be exculpatory: see, for instance, the legal principle that ignorance of the law is no defence (ignorantia juris non excusat). Ignorance here includes not understanding. But when the rule or rules in question go to constitute a practice, as chess is constituted by its rules, the 'wrong' committed by one who breaks a rule cannot be understood independently of the existence of the rule; ${ }^{2}$ it was this fact which threatened circularity in our account of promises, a circularity Anscombe avoided by invoking the learning and use of modals and logoi. The law against murder, by contrast, forbids something which is independently wrong or wicked, and here at least the rationale for the above-mentioned legal principle is pretty clear. But the inadvertent breaking of constitutive rules is surely prima facie excusable. This is in part due to the conventionality (arbitrariness, one might say) of the forms specified or assumed by the rules - e.g., the shape of a given chess piece, or the actions that embody the donation of something to someone. One who is unaware, or not fully aware, of the significance of these conventional forms doesn't thereby show a bad character.

In everyday life there are straightforward criteria for determining if someone knew he was meant to $\varphi$, although he didn't $\varphi$. If he knew he was meant to $\varphi$, he of course understood the relevant formula, 'You're meant to $\varphi$ '; so these criteria are also criteria for his understanding the formula. Here are some examples. If caught out, the person might admit he'd broken the rule; or if put on the spot and asked, 'Now what were you meant to do?' he might just tell us. Or again, we might have witnessed him readily following the rule in other circumstances; or - often noteworthy - he might have insisted on others' following the rule, been aggrieved when they didn't do so, and so on.

2. A practice like promising is necessary for the attainment of important human goods, as Anscombe argues, so the wrong involved in breaking a promise is not merely that of breaking some rule or other. 
Equally, there are everyday criteria for someone's not understanding a rule, or not knowing about it, or not knowing that it applied in a given situation. If he is still a learner, that itself is a fact with criterial weight. If an adult, then sincere expressions of surprise when we berate him for not $\varphi$-ing will indicate a lack of knowledge or understanding. Or he might have suffered a stroke with consequent amnesia. Et cetera.

With language-mastery in general, the default position is that a person above a certain age and of normal intelligence will understand the words he is using, or which others use when talking to him. ${ }^{3}$ This default position is not something that we adopt for pragmatic or epistemic reasons; it is not, e.g., based on inductive assessments of the probability of someone's understanding something. (The past 'evidence' for such an assessment would have to include a great deal of unquestioned linguistic intercourse - unquestioned because the default position is that people know what their words mean!) Rather, the nature of this default position is similar to that described by Anscombe in her article, 'On Brute Facts' (Anscombe, 1981b).

In 'On Brute Facts', Anscombe discusses the move from certain premises to a conclusion like ' $X$ owes $Y £ 10$ '. (The premises could include ' $X$ ordered potatoes from Y', 'Y delivered a sack of potatoes', etc.) For this human practice to be possible (= practicable), moves or inferences of this sort must be allowed to stand in the absence of defeating circumstances; that is to say, if certain facts hold, the default position is that X owes money to Y. Defeating circumstances are circumstances such as: that half the potatoes were rotten; that the bag was left two miles from X's house; that $\mathrm{X}$ and $\mathrm{Y}$ were both acting in a film. It is not possible in advance to state exhaustively what may count as defeating circumstances - again, not for 'pragmatic reasons', but rather because of the fluid and creative nature of human institutions, and because of the 'imponderable evidence' on which we so often rely in our dealings with our fellow human beings. ${ }^{4}$

For linguistic intercourse to be possible (= practicable), it is likewise necessary that a person is taken to be 'playing the language-game' in the absence of defeating circumstances. And this is obviously so for the sorts of language-games I've been alluding to, such as that of promising. Earlier, I mentioned two sets of criteria, those for determining understanding and those for determining lack of understanding, and it is in fact the second of these which is going to be more pertinent to our question, 'What is the difference between

3. We should perhaps add that the person 'belongs to the linguistic community', since no one will understand what's said in an unfamiliar language. But to belong to a linguistic community is simply to understand a whole lot of words and expressions (as speaker, reader, audience...); so the 'default position' I'm referring to is not adopted prior to talking and listening to someone, but itself crystallises in those moments during which one's interaction with the person enables one, through a host of contextual and other 'clues', to proceed automatically in one's dealings with them as with a speaker of English (French/Catalan/ Hindi...).

4. The phrase is Wittgenstein's; see PI, II xi, p. 228. 
my failing to grasp that I should keep a promise and my simply ignoring the obligation which I have put myself under?' If you are an adult of normal intelligence, and you say 'I promise I'll take you to the airport', then your subsequent protestation that you didn't know what promises were will not be allowed any weight unless you can plausibly cite some (rather extraordinary) circumstance, capable of defeating the default assumption of linguistic competence. ${ }^{5}$ It is not for us to invoke criteria of understanding, it is for you to invoke criteria of non-understanding.

It is tempting to 'look inwards' here in the manner of Descartes and insist that whatever I did and said, and whatever the external circumstances, my understanding of my own words, or lack of it, is a purely internal - perhaps even private - matter. I will not here rehearse the critique of the Cartesian picture which we find in the later Wittgenstein, beyond saying this: insofar as the desire to 'look inwards' arises from the recognition that it can always turn out that someone didn't after all understand what he was saying (e.g.), this latter fact is central to, and accounted for by, the picture adumbrated above, with its reference to default positions, criteria and defeasibility.

\section{Abilities and inclinations}

Teaching language means teaching abilities - in other words, training. The bare notion of an ability or skill differs from that of an ethical virtue, in a way delineated by Aristotle (and later by Aquinas). An ethical virtue like honesty involves not just the ability to give a customer the correct change (say), but the desire or inclination to do so. By contrast, being good at spelling amounts, roughly, to being able to spell words correctly if you want to. For this reason, misspelling a word on purpose doesn't impugn your skill as a speller in the way that misspelling it inadvertently does; whereas walking off with someone else's wallet on purpose impugns your claim to be honest while walking off with it accidentally does not.

When we teach a child the use and meaning of modals like 'You have to' and 'You cannot', we aim to bring it about that the child regularly forms the inclination to $\varphi$ when he has understood that he 'has to' $\varphi$. Indeed, as was said above, it would seem to be a criterion of his understanding the modal that he responds appropriately, i.e., voluntarily js, often enough. Thus, in teaching this bit of language, we are not imparting a mere ability, if that means the ability to do $\mathrm{X}$ if one wants to (to do $X$ being to $\varphi$ in response to 'You have to $\varphi$ '). We are aiming to impart a readiness or inclination to do certain things. A child who never responds appropriately to 'You have to $\varphi$ ' may be said not to have mastered the language game at all; one who responds appropriately but not often enough will either be deficient in understanding or deficient in will - which of these it is will depend on whether, and to what extent, we can appeal to the

5. As is hinted in footnote 3, the term 'assumption' is not a psychological one. Shared 'assumptions' are manifest in human procedures. 
sort of criteria of (non-)understanding discussed earlier. What I have called deficiency in will might, depending on the case, strike us as deficiency in virtue (naughtiness), or slowness to acquire virtue, or some such. We will be more likely to talk of imperfect virtue where the case is that of the modals governing the promising language game than where it is that of the modals governing the playing of chess. Deficiency in will as regards playing by the rules in chess would look like boredom, or contrariness, or whim. (Which is not to say that these phenomena lie outside 'the ethical'.)

In fact the teaching of language quite generally aims to instil more than just the ability to use words correctly. It is not enough that the learner can give the correct answer to ' $\mathrm{a}+\mathrm{b}=$ ?' when he wants to; he also needs to be someone who generally does want to give the correct answer, in the sense that this is his default inclination: he is not someone who quite often feels like giving an incorrect answer, for instance. Indeed, as we have seen, a person will only count as understanding the meaning of 'plus' if he often enough gives the correct answer, so that it is rather hard to coherently depict a child who can give the correct answer when he wants to but can't be relied on to want to. (It is somewhat easier if we are depicting an adult.) In the case of imperatives and stopping/forcing modals, however, the voluntary actions which we desire to see the language learner performing are not just linguistic actions, i.e., uses of the very words which it's to be hoped the learner is learning - the voluntary actions we desire to see the learner performing are those ordered or required, i.e., those mentioned in the imperative or modal statement. The idea of deficiency of will has a ready application to those who don't do what they have to, or don't do what they're told: human motives for non-compliance or disobedience are often perfectly natural, flowing from our human nature. ${ }^{6}$ Motives for misusing words are not in this sense humanly natural; quite a lot of scene-setting and circumstantial detail are needed to depict a scenario in which the diagnosis 'He wants to use that word wrong' has any appeal.

The person who has properly learnt the meaning and use of 'You have to $\varphi$ ' will be disposed to $\varphi$ in response to that statement, ceteris paribus. That last phrase is intended to cover such defeaters as: recognition that the statement was a joke, recognition of pressing reasons not to $\varphi$, recognition that no suitable logos is forthcoming, and so on. In the extreme case, a reflective adult may find reason to reject the very practice constituted by the rules in question. Absent such rational rejection, the person, as I have said, will be inclined (disposed) to act in accordance with the statement: the actions they consequently perform will be voluntary and intentional. Anscombe foregrounded an agent's actual or possible responses to 'Why?' as indicative of intention or the lack of

6. And of course we mustn't forget the frequently imperfect behaviour of parents towards their children, including in the context of teaching or training; a child's resistance or 'naughtiness' might be a form of self-protection, or expressive of a craving for love, or any number of things - rather than straightforward 'deficiency'. 
it (see Anscombe, 1963); and here the question, 'Why are you $\varphi$-ing?' gets its answer courtesy of the language-game itself. For the agent will be able to reply using the relevant logos - for example, 'Because I promised to'.

The adult who has fallen into the habit of lying, cheating or breaking promises does not (as I have argued) have the excuse of non-understanding ready to hand. In the absence of defeaters, the presumption of competence stands, and our diagnosis will be one of 'deficiency of will' - which does not mean weakness of will, but rather a defective orientation of the will (a wrong ordering of priorities, weighing of practical reasons, etc.). The ordinary word for such a person is 'dishonest'. Such a person knows what 'You cannot' and 'You have to' mean; and indeed the bare ability to play the language-game may be alluded to by some such remark as, 'He knows well enough how to keep an undertaking if he wishes to impress the boss'. He can do X if he wants to. It's just that too often he doesn't want to.

But this last fact will indicate that such linguistic training as he received in childhood did not achieve its true aim. For the aim of teaching a child the modals 'You have to', etc. is precisely to instil a standing inclination to 'respond appropriately' to them. The language games in question, after all, have a human point, they play a real role in our lives. The aim of the teaching was not to instil a mere ability. So although we do say of the dishonest adult that he understands what it is to make a promise, answer a question truthfully, etc., we can in the same breath say that he has not learnt what society was, in a sense, trying to teach him.

\section{Illusion and confusion}

This reference to what society is 'up to' should not be thought of as ruling out the possibility that society, or social groups, should themselves fall into habits of dishonesty. In a certain sense, it can become the norm - or at any rate become normal - for people to break the rules, or twist the rules, for ulterior motives, conscious or unconscious. The more this happens, however, the closer we get to a state of linguistic and practical confusion. The meanings of words become unfocused; people's accounts of what they are doing become detached from their real, more or less unconscious aims. This kind of confusion is a species of conceptual corruption.

What shows that a prevalent use of a term or set of terms involves, not merely false beliefs, but confusion? The answer is: the tangles, dead ends, contradictions, empty statements and even plain nonsense into which such use leads people. Where the use of the terms in question is bound up with action, people's behaviour may show a corresponding incoherence: its significance will often be obscure, including to the agents themselves.

In 'Modern Moral Philosophy', Anscombe famously argued that 'the concepts of obligation, and duty - moral obligation and moral duty, that is to say - and of what is morally right and wrong, and of the moral sense of "ought", ought to be jettisoned if this is psychologically possible; because they are sur- 
vivals, or derivatives from survivals, from an earlier conception of ethics which no longer generally survives, and are only harmful without it' (Anscombe, 1981c: 26). If she was right, a way of using the word 'moral' had become prevalent, and this way of using it should be jettisoned. But if meaning is use, how can this be? If people are prevalently using a word a certain way, the word surely has a meaning; and the only available criticism of anyone who uses the word thus will surely be that they have said something false. The use of the word can't itself be criticised. So it might be argued.

It is a natural line of argument, and it might seem to follow from the idea expressed by Wittgenstein when he wrote: 'If language is to be a means of communication there must be agreement not only in definitions but also (queer as this may sound) in judgments' (PI 242). But of course Wittgenstein is here stating a necessary, not a sufficient, condition of language's being a means of communication. There might be prevalent agreement that such-andsuch is 'morally obligatory', although the expression 'morally obligatory' is in truth devoid of real sense, and no genuine communication is achieved by means of it. This is precisely the picture which Anscombe paints for us. The 'prevalent use' turns out to be prevalent nonsense. In virtue of what?

One key aspect of the use of 'moral obligation', 'morally ought', etc., as depicted by Anscombe is that all sorts of reasons for doing something are rejected as inadequate. Reasons that cite what is needed (e.g., for a human being's health), or that cite established rules or customs, or that cite commands - none of these, it is alleged, touch the important issue, which is: What action am I morally obliged to do? For can't I always ask, 'But ought I to aim for what is needed, or what is dictated by rules, or what is commanded?'. Now it is true that one often can ask some such further question, especially about commands, for instance. But a general dissatisfaction with all 'factual' reasons raises the question: What can 'I ought to $\varphi$ ' amount to, if there can be no substantive reasons that fully support that judgement? The result of not accepting any substantive reasons as adequate answers to 'Why ought I to do that?' is to make that question futile and empty - and also that particular use of 'ought'. I am not suggesting that every instance of the question 'Why ought I to do that?' will in fact have a substantive answer, for explanations run out somewhere and no answer can be given to one who asks, 'Why ought I to treat matchsticks as less valuable (more dispensable) than human beings?' The criteria determining what are good, bad, intelligible or unintelligible answers to the question 'Why?', in the context of a particular kind of enquiry, cannot themselves be interrogated by that question; and the fact that enquiry is a sort of social practice involving human beings gives a clue as to why the quoted question is a senseless attempt to interrogate such criteria. And it is worth noting that nothing would be achieved - or even said - by making out that there is simply a moral obligation to treat matchsticks as less valuable than human beings.

7. What follows is both a condensation and an elaboration of what Anscombe says about this in 'Modern Moral Philosophy'. (Not as paradoxical as it sounds.) 
'You have to give reasons why lemurs (or matchsticks) ought to be treated as less valuable than human beings: we need grounds for this alleged moral obligation'; 'You tell me that it would be dishonest to do this, but is there a moral obligation to be honest?' In such statements, as characteristically used, the phrase 'moral obligation' does no real work. We felt as if we were saying something important when in reality we were saying nothing. For we in a sense forgot the point of certain language games, e.g., those in which reasons for action are asked for or given.

Anscombe connected her account of the prevalent use of 'moral obligation', 'morally ought', etc. with a diagnosis: aspects of that use are explicable by reference to an earlier belief system, one involving divine commands. Without this belief system, she argued, an expression like 'ought' - used in the way she was depicting - had 'become a word of mere mesmeric force' (ibid., 32). But it should be noted that Anscombe's genealogical diagnosis is optional. The important thing is the futility of what people are doing with language, a futility which they themselves do not recognise. ${ }^{8}$ To quote Wittgenstein again: 'a wheel that can be turned though nothing else moves with it, is not part of the mechanism' (PI 271). What is interesting is that there can be a widespread illusion that a wheel is part of the mechanism which in fact isn't part of the mechanism. If all this is correct, Anscombe's view does not stand or fall with the genealogical diagnosis (in terms of the earlier belief system): her description of use is what is crucial. And the use of these words is bound up with how people act. The problem is thus not a 'merely' theoretical one - it is also a practical one. Indeed, Anscombe's main motive for critiquing the confused use of 'moral obligation', etc. is that this use naturally leads to, or lends itself to, people's abandoning considerations of (in)justice in favour of considerations of what is expedient, in the context of actual practical deliberations. ${ }^{?}$

Futility will evidently infect language games involving stopping and forcing modals if it becomes normal to respond with indifference to 'You're meant to', 'You can't', etc. The futility might not go unrecognised, in which case the language-game in question is liable to become a shell of its former self, or simply die out. This may well be true of various forms of etiquette, for example. But we should remember that etiquette blends with morality. If the prevalent response to 'You wronged X, so you should apologise to X' (logos followed by modal statement ${ }^{10}$ ) comes to be one of indifference, i.e., if the

8. 'Prevalent' does not mean 'universal'. Anscombe clearly did allow that someone who calls such-and-such 'morally obligatory' might mean something quite intelligible - as, that not doing such-and-such would be unjust, would wrong somebody. This would come out in what further things the person said (or did), e.g., by way of explanation.

9. See Anscombe (1981c: 38-42; from 'I will end by describing...' to the end of the article).

10. 'You wronged $X$ ' and 'You should apologise to $X$ ' are not learnt as part of a 'package deal', in the way in which 'It's mine' and 'You can't take it' are. While the concept of apology is dependent on that of wronging someone (viz. the person to whom apology is owed, typically), the reverse doesn't hold - particularly in view of the fact that 'wronged $X$ ' is an 
act-type apologising becomes sufficiently rarely instantiated, then the status of 'You should apologise' will approach that of the wheel that can be turned though nothing else moves with it. In the beginning is the deed, in the end is nonchalance.

Illusion that a wheel is part of the mechanism when in fact it isn't attends the situation in which 'You're meant to' comes to be used as if there were logoi to back it up, or (more specifically) comes to be backed up by ersatz logoi. The language of rights often seems to involve this species of illusion/confusion, as when 'I've a right to such-and-such' gets backed up by a more or less arbitrary logos - as it might be, 'Other people who are no better than I am have suchand-such'. The purpose of the linguistic move is to seem to be playing a trump card when one has no trump card to play. This is most likely a subconscious or unconscious purpose, however, and the person proclaiming his right might feel genuinely aggrieved if it is not respected. The continuation of this state of affairs is made possible by (among other things) the attractiveness of certain roles: occupier of the moral high ground; person with a complaint; person deserving of our sympathy; person to whom airtime and limelight are owed. Whether this particular phenomenon is sufficiently widespread as to merit the soubriquet 'conceptual corruption' is an empirical matter, one that is beyond the scope of this essay. But it is hard to deny that public discourse offers many instances of the sort of thing I am talking about: language being used for ulterior motives, as we might put it.

\section{Travails of internalism}

A person who has properly learnt the meanings of stopping/forcing modals, I have argued, is someone who is not merely able, but inclined, to 'respond appropriately' to their use, ceteris paribus. The picture of human agency which emerges from this is at odds with a popular philosophical position, viz. "internalism' about reasons for acting. ${ }^{11}$

For an internalist, a person can have reasons for $\varphi$-ing only if $\varphi$-ing is somehow conducive to the satisfaction of that person's desires. (Obviously this formula can be tweaked in various ways, according to the version of internalism in question.) Let's imagine that you and I are playing chess, and you threaten my king with your rook. Perhaps observing my hesitation, you say, 'You have to move your king, it's in check' - forcing modal followed by logos. According to what I've been arguing, the following is true: if I have properly learnt ${ }^{12}$ the meaning of forcing modals, know the rules of chess, and see no

abstraction from such particular cases as 'insulted X', 'maimed X', etc. But this doesn't prevent our calling 'You wronged X' a logos. The case is like the one earlier alluded to: 'The music has stopped, so you have to sit down'.

11. See, e.g., Williams (1981), Smith (1987).

12. For the sense of this phrase, see the concluding paragraph of sect. 2: you won't have properly learnt the meaning and use of modals if you have failed to acquire, or have lost, a standing inclination to respond appropriately to them. 
defeating circumstances in view, then I will move my king, unless somehow prevented from doing so. My action will be intentional - I will be ready with a reason if asked, 'Why did you do that?', my reason being 'My king was threatened'. At this point, an internalist may say either or both of two things: (a) neither the statement 'You have to move your king' nor the statement 'Your king is in check' nor the conjunction of the statements can, in itself, give me a reason for moving my king; (b) the circumstance that I don't want to move my king (or: play by the rules) is in a trivial sense a possible defeater, since if I don't want this, I have no reason to move my king.

Taking (a) first, we might start by asking, 'If that isn't a reason for action, what is?' But this sort of appeal to common sense is likely to be shrugged off. A more direct attack is to ask the internalist what sort of meaning and use can be ascribed to 'You have to $\varphi$ '. The answer is liable to be that such a formula is either merely factual or merely imperatival: it is thought that each of these options leaves room for the rational agent to treat or not to treat the formula as supplying a reason, according to her own subjective preferences.

'Factual' indicates some claim along the following lines: 'You have to move your king' means 'By the rules of chess, any move here other than moving your king is not a genuine chess move'. The claim fails for at least two reasons. First, the rules of chess do not simply state what actions shall be called 'chess moves', something that can be seen in the distinction between breaking a chess rule and doing something other than moving. By the rules of chess, scratching one's head is not called a 'chess move', but if I scratch my head I haven't thereby broken a rule of chess. ${ }^{13}$ Second, the rules of chess in fact include such rules as that you have to move or defend your king when it is threatened. ${ }^{14}$ So the proffered explanation of 'You have to move your king' is viciously circular by virtue of its mention of 'the rules of chess'.

As for the claim that 'You have to $\varphi$ ' is a mere imperative, we have already seen that this is mistaken. Forcing modals differ from imperatives in being conceptually tied to logoi. And it is significant that it is a logos that I am likely to give as my reason when asked 'Why did you do that?'

13. It might be said that the rules of chess are silent as to whether scratching one's head is called a 'chess move'. Independently existing rules of word use are what preclude calling scratching one's head a 'chess move'. - The phrase 'independently existing' is suspect, since the concept chess move only exists once the rules of chess exist. But in any case, the rules of chess are (pace the position under discussion) quite generally silent about word use. Calling a legal move of the white king a 'chess move' is not prescribed by the rules of chess. In teaching a human being the rules of chess, we do indeed introduce words, e.g., by saying, 'This [pointing] is the white king'. But (a) we are not thereby stating a rule of chess, as the presence of the demonstrative shows, and (b) we don't, and couldn't, introduce 'chess move' in such a way. You learn what 'chess move' means by learning how to play chess - or by learning the concept move in the context of other games and learning that there's a game called 'chess' in connection with which that concept is used.

14. That is to say, if you can do so without breaking another rule; if you can't, you're checkmated. This mention, within a rule, of other rules of the game aptly illustrates how the rules of a practice must be learnt as a 'package deal'. 
What about (b), above? In response to your statement 'You have to move your king; it's in check', I say, 'Ah no; you see, I don't want to move my king.' Do I mention a defeating circumstance, in the sense in which the grocer's leaving a bag of potatoes two miles from my house is a defeating circumstance relative to both 'He delivered the potatoes' and 'I owe him $£ 10$ '? Clearly not. What count as 'defeating circumstances' is determined by the practicalities of the given practice and (thus) of its attendant language-game; in general - though not always - an agent's mere lack of inclination to abide by one of the rules constitutive of a practice cannot be taken as, and so is not, an adequate reason for their not abiding by it.

It is often a truism to say that someone will only do something if she wants to. If I don't want to move my king I won't do so; ditto, if I want not to move it. ${ }^{15}$ But these truisms give no support to internalism about reasons for acting. What people do and what people want can after all be unreasonable, even irrational. And it is often the rules of a practice that determine what rationality and irrationality amount to.

Consider language use itself. Language is governed by rules: you can't call that a 'fox' (it's a flamingo), you're meant to say 'Yes' (if that's the answer), you may call this shade 'blue' (or 'green'). Here are Anscombe's modals in play. ${ }^{16}$ A philosopher says, 'I have no reason to $\varphi$ unless I want to'. Being sincere, she takes herself to be saying something true. Whether it's true depends on what, e.g., the word 'want' means in her statement. Could she say: 'I want to use this word in conformity with the rules governing its use - so I will'? But how is she using the word 'want' in that statement? That she uses words in conformity with the rules is a presupposition of her saying anything at all; she cannot decide to use words correctly, since the content of any such decision will already have committed her to the 'aim' of using words correctly. And yet following rules is, for the internalist, something one only has reason to do if doing so fits in with one's desires.

Could the philosopher perhaps think, 'I want to use the word "want" in conformity with the rules governing its use - so I will'? If she thinks the thought in English, the same argument will apply as above. If she thinks it in a private language - putting aside conceivable qualms about such a notion - she must still take it as moot whether she wants to abide by the rules of this private language, including the rule governing 'I want'. (You are to take both occur-

15. The truism shouldn't be taken as a universal truth; after all, ordinary usage certainly allows 'I did what I had to, though I really didn't want to.'

16. A child first learns to use words correctly and only later learns the meaning of such a formula as 'You can't say that (use that word here, etc.)'. Language is rule-governed, though its speakers don't need to have such concepts as 'rule', 'have to' or 'cannot' in order to count as linguistically competent. There must, however, exist practices of correcting and confirming within a linguistic community, and a community in which articulate reflection upon such practices is possible will be one in which Anscombean modals (or equivalents) get used. What of the logoi to be used in conjunction with these modals? These are very various in kind; some enjoy a conceptual interdependence with their correlative modal statements ('You can't call him Mark, his name is Max'), and some do not. 
rences of (inflexions of) 'want' in the previous sentence as standing proxy for putatively private symbols.) So the same argument goes through: for her to say that she does want to abide by that rule involves positing a certain decision as a rational prerequisite of itself - a nonsense.

If pushed to its logical conclusion, internalism about reasons for acting thus appears to result in a commitment to the ineffability of a certain kind of 'mental content'. An internalist must cite the desire to follow linguistic rules as that which gives the speaker reason to follow those rules, in the sense that if he lacks such a desire his breaking the rules cannot be deemed irrational (hence subject to criticism); and the content of this desire must be regarded as being determined independently of all rule-governed meaning. For the internalist conceives of a person as 'equipped' with some standing desires, in light of which he will have reason to do some things and not others - and these desires will have to include the desire to use 'desire' in conformity with linguistic rules, public or private. But he cannot express, to himself or to others, the content of this desire (the one with which he is already equipped). To do so, he would have to have already made the decision (to use 'desire'...) which we are envisaging him as now rationally making. In fact, the identity of the standing desire must float free of all norms, public or private. ${ }^{17}$ In which case it is hard to see how it could be compatible or incompatible with anything at all. 'So in the end when one is doing philosophy one gets to the point where one would like just to emit an inarticulate sound' (PI 261). Moreover, in any actual context of philosophical debate real words must be utilised. Ineffable thoughts are not on the table.

So how should we think about the matter? We imagined the philosopher saying, 'I have no reason to $\varphi$ unless I want to'. The question we face - that which flummoxed the internalist - is: 'Did she have a reason for using the word "want" in accordance with the linguistic rules that govern it?' In other words: "Why did she use the word "want" in accordance with the linguistic rules that govern it?' Now the question 'Why?', in its reason-demanding sense, is susceptible of a large variety of kinds of answers. Such answers typically depend on what the person asking the question is after. Does he have in mind some reason why it would be a good idea to break the linguistic rules in this situation? (Perhaps he takes it that the speaker is, in fact, attempting to illustrate certain common misuses of words.) In the absence of some such explanation for his enquiry, it is not clear what sort of answer can be given, unless it be 'There's no reason to break the rules here'. If that is allowed as a positive answer to 'Why?', then we may say that the speaker intentionally conformed to the linguistic rules when she spoke. But it is an odd saying. The facts are:

17. An internalist who is content with a third-personal, behaviouristic conception of desire might embrace the ideas of norm-free desire and of norm-free practical rationality. A person desiring to follow linguistic rules would on this account simply be, in effect, one who did in fact (often) conform to those rules, as a calculator might be said to conform to arithmetical rules. Apart from anything else, this view makes no room for that asymmetry between linguistic competence and incompetence which I go on to discuss. 
she is a normal adult and she was speaking English. Hence, she was following certain rules.

Could the internalist say some such thing? That is, could he make out that people use language, and hence follow linguistic rules, without having reasons for following these rules? The problem is that the internalist cannot do justice to the asymmetry between following rules and breaking rules. According to the internalist, if someone who does $\mathrm{X}$ has no reason for doing X, it is because he has no operative desire to do X. This might make room for 'just following' linguistic rules, but if it does, then it will at the same time make room for 'just breaking' linguistic rules: if I lack the desire not to break the rules, I cannot be deemed irrational when I break them. But misusing language for no reason at all is a paradigmatic manifestation of irrationality - while one who 'systematically' misuses language lacks an intellectual and practical capacity (so perhaps no more misuses language than does a gurgling baby). Conversely, ordinary fluent language use, i.e., following the rules, is a paradigmatic manifestation of human rationality.

'Ceteris paribus, one has reason to follow (not break) the rules governing the uses of words' is true enough. But if there is a 'Why?' question corresponding to this truth, it is something like: 'Why go in for linguistic communication at all?' In response to this question, we can perhaps point to all the many benefits of having language, as we can point to the benefits of going in for promising. However, it is not as if it is an option for us to give up using language; so the form of the question is misleading. It would be better if it were rephrased along these lines: 'What are (some of) the benefits of having language?' - a question of about the same level of generality as 'What are (some of) the benefits of being able to move around in space?'

\section{Conclusion}

Let me summarise these investigations. Understanding language is manifested in using language, which is a kind of human activity. In teaching a person the meanings of words, we aim to instil in them an ability, but not, typically, a mere ability: we aim, in fact, to instil an ability and an inclination - namely, to use such-and-such words correctly. (To say this need not be to impute to the learner an intention to use those words correctly; that way of putting it is probably an over-intellectualisation.) In the specific case of stopping and forcing modals, we additionally aim to instil the inclination to do (or not do) whatever is mentioned as what you 'have to' or 'cannot' do. The criteria for a learner's understanding the meanings of such modals include her often enough doing (or not doing) the relevant things. An adult may count as understanding what the modals mean despite having developed an erratic inclination, or even disinclination, to do what she is meant to do, etc., on account of (a) the default assumption that speakers know the meanings of the words in their language, and (b) the existence of criteria for knowing and (more significantly) for not knowing the meanings of words, or not knowing that they apply 
here. In the absence of any of these latter criteria, the 'default assumption' (defeasibly) stands.

It is possible for it to become the norm, or at least normal, for people (e.g., in some societal group) to fail to respond appropriately to stopping and/or forcing modals of one kind or another. The more this is true, the less clear the meaning of what they say and do will be. Conceptual corruption and consequent widespread forms of nonsense are humanly possible; Anscombe proposed that this picture in fact held true, at the time when she wrote and at least as regards the philosophical community, of such terms as 'moral obligation' and 'the moral ought'. It seems hard to deny that public discourse offers various instances of this sort of linguistic and practical vacuity.

It is natural and tempting to regard thought, will and understanding as logically independent of action. The foregoing reflections on the meaning of Anscombean modals help to undermine this notion. (They are not the only reflections to do so.) Understanding, meaning and action are here closely intertwined. An internalist about reasons for action can be seen to buy into the mistaken notion of logical independence insofar as he claims (a) that rational action can only occur when an agent has a 'motivating reason' to do something, and (b) that one only has reason to follow a rule or rules insofar as doing so is conducive to the satisfaction of one's standing, or prior, desires. But desiring to follow the rule 'In circumstances $C$ you have to $\varphi$ ' presupposes knowing the meaning of 'You have to', ' $C$ ' and ' $\varphi$ '. The criteria for understanding the meaning of these terms, however, include doing what you 'have to'. Thus desire to follow a rule is here logically posterior to action.

In connection with the rules governing the use of words (symbols), the internalist claim founders in dramatic fashion; for it can be said to commit the internalist to the nonsensical idea that the relevant desires are independent of the agent's doings even to the extent of those desires' having ineffable content - from which it would follow that no distinction could be made between what would, and what would not, be conducive to their satisfaction.

In using language, or in having articulate thoughts, one thereby follows certain rules and in that sense can be thought of as 'responding appropriately' to the modal statements expressive of those rules. This is what constitutes the rationality of one's talk or thought; it is not constituted by any conformity of rule-following with standing desires. ${ }^{18}$

\section{Bibliographical references}

Anscombe, G.E.M. (1963). Intention, $2^{\text {nd }}$ ed. Oxford: Basil Blackwell.

- (1981a). "On Promising and its Justice". In: Ethics, Religion and Politics: Collected Philosophical Papers Vol III. Oxford: Basil Blackwell, 10-21.

- (1981b). "On Brute Facts". In: Ethics, Religion and Politics: Collected Philosophical Papers Vol III. Oxford: Basil Blackwell, 22-25.

18. Thanks to Richard Gipps for helpful feedback on an earlier draft of this paper. 
— (1981c). "Modern Moral Philosophy". In: Ethics, Religion and Politics: Collected Philosophical Papers Vol III. Oxford: Basil Blackwell, 26-42.

- (1981d). "Rules, Rights and Promises". In: Ethics, Religion and Politics: Collected Philosophical Papers Vol III. Oxford: Basil Blackwell, 97-103.

Smith, M. (1987). "The Humean Theory of Motivation". Mind, 96, 36-61.

Williams, B. (1981). "Internal and External Reasons”. In: Moral Luck. Cambridge: Cambridge University Press, 101-113.

Wittgenstein, L. (1958). Philosophical Investigations (2nd ed.), trans. G.E.M. Anscombe. Oxford: Basil Blackwell.

Roger Teichmann is Lecturer in Philosophy at St Hilda's College, Oxford. He is the author of a number of monographs, including The Philosophy of Elizabeth Anscombe (OUP 2008), Nature, Reason and the Good Life (OUP 2011) and Wittgenstein on Thought and Will (Routledge 2015). He edited the four-volume Elizabeth Anscombe: Critical Assessments of Leading Philosophers (Routledge 2016).

Roger Teichmann és professor de filosofia al St Hilda's College, Oxford. És autor de diverses monografies, com ara The Philosophy of Elizabeth Anscombe (OUP 2008), Nature, Reason and the Good Life (OUP 2011) i Wittgenstein on Thought and Will (Routledge 2015). Ha editat els quatre volums d'Elizabeth Anscombe. Critical assessments of leading philosophers (Routledge 2016). 